\title{
A cultura politica em ação. Diálogos institucionais entre a Coroa e os centros urbanos em Portugal no século XIV
}

\author{
Political Culture in Action: Institutional Dialogue between the \\ Crown and Urban Centers in Fourteenth-Century Portugal
}

\author{
Adelaide Pereira Millán dA CostA \\ Universidade Aberta/Instituto de Estudos Medievais da FCSH \\ delaide.Costa@uab.pt
}

\section{RESUMO}

Este artigo defende que o conceito de cultura política é operativo para apreender as várias componentes do ambiente mental e funcional que agiam no processo e nos fundamentos do diálogo estabelecido entre a coroa e os concelhos, no reino de Portugal, em meados do século XIV. Tendo em conta esta premissa, foram analisados 292 capítulos especiais de cortes, apresentados nas assembleias de 1325, 1331, 1352 e 1361, não com o propósito de captar os objetivos que os concelhos pretendiam ver consignados mas de identificar os alicerces argumentativos que utilizavam para tal, exprimindo a perspetiva concelhia da referida cultura política.

Palabras clave: Portugal, Poder real, Municípios, Cortes, Século XIV.

\begin{abstract}
This article defends the concept of political culture as a tool to approach different components of the mental and funcional environment that acted on the process and foundations of the dialogue established between the Crown and the Councils in the kingdom of Portugal in the mid-fourteenth century. Taking this premise into account, 292 special chapters of the Parliament, presented in the assemblies of 1325 , 1331,1352 and 1361 are analyzed, not with the goal of identifying the objectives that the Councils wanted to attain, but rather of identifying the argumentative basis they used for that purpose, expressing the said political culture from a municipal perspective.
\end{abstract}

Key words: Portugal, Royal Power, Municipalities, Parliaments, Fourteenth Century.

Sumario: 1. A cultura política - Uma categoria em definição. 2. Contextos do diálogo estabelecido entre a coroa e os concelhos. 3. A problemática, as fontes e os protagonistas. 4. Os argumentos concelhios e a apropriação da cultura política. 


\section{A CULTURA POLÍTICA - UMA CATEGORIA EM DEFINIÇÃO}

O conteúdo semântico das palavras com que se faz a História nem sempre prima por uma exata definição. Por vezes, o discurso historiográfico é contaminado pela receção e apropriação pouco esclarecida de conceitos de áreas científicas que nos são alheias, desgarrados da arquitetura teórica em que foram produzidos. Vem esta constatação a propósito da categoria cultura política. Conceito criado nos já longínquos anos sessenta do século XX por Almond e Verba ${ }^{1}$, no âmbito da ciência política, conheceu elogios, críticas e reformulações, vendo alteradas as suas caraterísticas primaciais ${ }^{2}$. Para além desta evolução no âmbito académico, a palavra vulgarizou-se no discurso quotidiano.

Nestas circunstâncias, comprimidos entre as mudanças de sentido a que o conceito foi sujeito na ciência política e o seu polimorfismo no senso comum, torna-se necessário precisar, de forma clara, o significado com que esta categoria é utilizada no presente texto.

Cultura política corresponderá ao conjunto de crenças sobre os fundamentos do poder e de normas sobre o seu exercício, partilhadas pelas várias estruturas que atuam num sistema político ${ }^{3}$. Trata-se de uma categoria compósita que integra a ordem jurídica, a cultura jurídica, a(s) ideologia(s) ou outros grupos de valores coerentes mas menos formalizados. Estes fatores tanto podem completar-se como concorrer entre si, em dissonância, mas todos se posicionam num horizonte de aceitabilidade. $\mathrm{Ou}$ seja, a partilha desta cultura não é sinónimo de completa anuência, mormente quando o sistema político se encontra em fase de construção e as entidades que o compõem não assumem um estatuto paritário em tal processo. A própria cultura política pode incorporar premissas que se vão alterando, fazendo-se substituir por outras, após algum tempo de coexistência, muitas vezes de fricção, entre ambas. Assim, num mesmo sistema existem apropriações diversificadas desta categoria, tornando-a flexível e adaptável a várias situações, de acordo com os protagonistas envolvidos.

Pensando no século XIV português, identifica-se uma subestrutura preponderante que é a coroa, imbuída do propósito de dominar o exercício do poder, mas à qual escapa a capacidade de impor, sem constrangimentos, tal objetivo. Os restantes corpos constituídos - senhores laicos, igreja e concelhos - defendem posições diferenciadas,

${ }^{1}$ ALMOND, Gabriel; VERBA, Sidney: The civic culture: political attitudes and democracy in five nations, Princeton, Princeton University Press, 1963.

${ }^{2}$ Para uma síntese sobre a evolução do conceito de Cultura Política veja-se OLICK, Jeffrey; OMELTCHENKO, Tatiana: "Political Culture", international Encyclopedia of the Social Sciences, $2^{\text {nd }}$ edition, ed. DARITY, William A., Detroit, Macmillan Reference USA, (2008), pp. 300-302.

${ }^{3} \mathrm{O}$ conceito foi depurado das bases em que assentava a sua definição canónica, uma vez que não se analisam as atitudes individuais subjetivas de perceção do sistema político mas as crenças e a ação dos grupos dotados de uma existência reconhecida nesse mesmo sistema. Sobre a definição de cultura política europeia (apreendida no tempo longo) vd. REINHARD, Wolfgang: “Qu'est-ce que la culture politique européenne? Fondement d'une anthropologie historique politique", Trivium, 2, (2008), (disponível em http://trivium.revues.org/902, consultado a 13 de Junho de 2012). 
escudam-se em distintas componentes da cultura política e, por vezes, os limiares do relacionamento ultrapassam-se, dando origem ao conflito aberto ${ }^{4}$.

Quando se pretende captar a cultura política em ação ${ }^{5}$, nada melhor do que escolher uma conjuntura relacional em que se produzam discursos que consignem as crenças e, em simultâneo, se ativem procedimentos reguladores do próprio diálogo institucional.

Ao tempo, o diálogo estabelecido entre a coroa e os concelhos ${ }^{6}$ era o que se filiava, com mais facilidade, nos esteios da cultura política emergente liderada pelos valores da coroa. As comunidades locais organizadas não defendiam uma concetualização alternativa dos alicerces do poder, plasmado em fontes da ordem jurídica (como o direito canónico) ou em valores (como a ideologia da nobreza), que contrariava os princípios defendidos pela monarquia. Dir-se-ia que os concelhos respeitavam as regras do jogo que os monarcas queriam impor, estabelecendo-se entre estas duas estruturas uma maior harmonia.

\footnotetext{
${ }^{4}$ Sobre o relacionamento estabelecido entre a coroa e outras entidades que agem no sistema político no século XIV, mormente nos reinados de Afonso IV e D. Pedro, veja-se MARQUES, A. H. de Oliveira: Portugal na crise dos séculos XIV e XV, Lisboa, Editorial Presença, 1987: Nova História de Portugal, dir. Joel SERRÃO e A. H. de Oliveira MARQUES, vol. 4, pp. 491-505; SOUSA, Bernardo Vasconcelos: D. Afonso IV, Rio de Mouro, Círculo de Leitores, 2005, pp. 97-136; MARQUES, José: "D. Afonso IV e as jurisdições senhoriais", Actas das 2as Jornadas Luso-Espanholas de História Medieval, vol. 4, Porto, Centro de História da Universidade do Porto, (1990), pp. 1527-1566; COELHO, Maria Helena da Cruz: "O poder e a sociedade ao tempo de Afonso IV", Revista de História, Porto, Centro de História da Universidade do Porto, 8, (1988), pp. 35-51 (disponível em http://ler.letras.up.pt/uploads/ficheiros/6442.pdf, consultado a 7 de Junho de 2012); id.: "O Arcebispo D. Gonçalo Pereira - um querer, um agir", IX Centenário da Dedicação da Sé de Braga. Congresso Internacional. Actas, volume II/1, A Catedral de Braga na História e na Arte (Séculos XII--XIX), Braga, Universidade Católica Portuguesa, Faculdade de Teologia, Cabido Metropolitano e Primacial de Braga, (1990), pp. 389-462; Id.: "Bispos e reis: oposições em torno de bens e jurisdições temporais", Lusitania Sacra, $2^{\mathrm{a}}$ série, 15, Lisboa, (2003), pp. 279-287 (disponível em - http://repositorio.ucp.pt/bitstream/10400.14/4463/1/ LS_S2_15_MariaHCCoelho.pdf consultado a 1 de Junho de 2012); VILAR, Hermínia: "No tempo de Avinhão. Afonso IV e o episcopado em meados de Trezentos", Lusitânia Sacra, 22, 2010, pp. 149-165 (disponível em http://re positorio.ucp.pt/bitstream/10400.14/4552/1/LS_S2_22_HerminiaVVilar.pdf, consultado a 3 de Junho de 2012).

${ }^{5}$ E não em textos teóricos em que a mesma se consubstancie.

${ }^{6}$ Para uma sistematização sobre os concelhos cf. MATTOSO, José: coord. A Monarquia Feudal (10961480), Lisboa, Círculo de Leitores, 1993: História de Portugal dir. José MATTOSO, vol. 2, pp. 205-241; COELHO, Maria Helena da Cruz; HOMEM, Armando Luís de Carvalho: coord. Portugal em definição de fronteiras (1096-1325). Do Condado Portucalense à Crise do Século XIV, Lisboa, Editorial Presença, 1996: Nova História de Portugal, dir. Joel SERRÃO e A. H. de Oliveira MARQUES, vol. 3, pp. 554-584, bem como todas as obras citadas ao longo deste texto. Um ponto da situação atualizado da investigação portuguesa desenvolvida sobre os concelhos medievais foi elaborado por COELHO, Maria Helena da Cruz: "Municipal Power", The historiography of medieval Portugal c. 1950-2010, Lisboa, IEM- Instituto de Estudos Medievais, (2011), pp. 209-230.
} 


\section{CONTEXTOS DO DIÁLOGO ESTABELECIDO ENTRE A COROA E OS CONCELHOS}

Partamos de um truísmo: a comunicação institucional estabelecida no âmbito de um sistema político processa-se nos moldes em que a cultura política vigente, esse repositório ativo de valores e de procedimentos, o permite.

Enunciemos os parâmetros da presente análise. Os protagonistas correspondem à coroa e aos concelhos e a circunstância de diálogo coincide com os momentos de realização de cortes, entre os segundo e terceiro quarteis do século XIV. Os discursos produzidos no âmbito deste relacionamento recuperam-se a partir dos textos em que os monarcas respondem aos pedidos formulados pelas cidades e vilas, reproduzindo, em parte ou na totalidade, o conteúdo dos mesmos?

Como já escrevi, a existência de uma cultura política partilhada não implica que todos os intervenientes se reconheçam plenamente nela. Por outro lado, trata-se de uma categoria suscetível de diferentes apropriações, sobretudo quando é equacionada em tempos do Antigo Regime. Basta pensar que a ordem jurídica, um dos seus mais determinantes elementos constitutivos, era plural e resultava da ação dos vários corpos sociais e políticos ${ }^{8}$.

Do lado da coroa, contingentes de juristas ${ }^{9}$ tentavam moldar as especificidades da ordem jurídica, quanto mais não fosse pela atribuição aos monarcas da capacidade de ditar a norma a aplicar a cada caso, de entre as múltiplas existentes ${ }^{10}$. Sem aprofundar as bases da ideologia régia que desde há uns reinados se vinha a construir ${ }^{11}$, atualizemos as conclusões de Carvalho Homem relativas às teorias do poder veiculadas nos preâmbulos dos atos legislativos coevos: enfatiza-se a origem divina do poder régio, os seus fins (bem comum) e a sua relação com a moral ${ }^{12}$.

\footnotetext{
${ }^{7}$ Veja-se infra o desenvolvimento deste tópico.

${ }^{8}$ Consulte-se o capítulo "Pluralismo jurídico del tardo medioevo. Derecho comúm y derechos particulares", in GROSSI, Paolo: El orden jurídico medieval, Madrid, Marcial Pons, 1996: col. Monografias jurídicas, pp. 221- 232; DUARTE, Luís Miguel: Justiça e criminalidade no Portugal medievo (1459-1481), Lisboa, Fundação Calouste Gulbenkian/FCT, 1999, pp. 99-148.

9 Vejam-se, por todos, os trabalhos de HOMEM, Armando Luís de Carvalho: O Desembargo Régio (1320-1433), Porto, INIC/CHUP, 1990, pp. 213-229; id:, "Subsídios para o estudo da administração central no reinado de D. Pedro II", Portugal nos finais da Idade Média: estado, instituições, sociedade política, Lisboa, Livros Horizonte, 1990, pp. 63-107. Sobre a investigação desenvolvida em Portugal ao nível das instâncias centrais de poder, veja-se HOMEM, Armando Carvalho: "Central Power: Institutional and Political History in the Thirteenth-Fifteenth Centuries", The historiography of medieval Portugal c. 1950-2010, Lisboa, IEMInstituto de Estudos Medievais, (2011), pp. 179-207.

${ }^{10}$ HESPANHA, António Manuel: História das Instituições. Épocas Medieval e Moderna, Coimbra, Livraria Almedina, 1982, p. 155.

11 Veja-se A génese do Estado Moderno no Portugal Tardo-Medievo (séc. XII-XV). Ciclo temático de conferências organizado pela Universidade Autónoma de Lisboa no ano lectivo 1996/97, coord. de COELHO, Maria Helena da Cruz e HOMEM, Armando Luís de Carvalho, Lisboa, Universidade Autónoma de Lisboa, 1999.

${ }^{12}$ Uma vez que os atos legislativos estudados por Carvalho Homem são emanados de D. Dinis e de D. Afonso IV, a cronologia do seu estudo cruza-se, sem coincidir na íntegra, com a cronologia do presente trabalho. Veja-se HOMEM, Armando Luís de Carvalho, "Dionisius et Alfonsus, Dei Gratia Reges et Communis Utilitatis Gratia Legiferi”, Revista da Faculdade de Letras, Porto, II a série, XI, (1994), pp. 11-110 (disponível em http://ler.letras.up.pt/uploads/ficheiros/2119.pdf consultado a 11 de Junho de 2012).
} 
Para além das declarações de princípio, os monarcas agiram. Reconhece-se, em especial a Afonso IV, um ímpeto legislativo extensivo a várias áreas, com predomínio para a normalização da justiça processual e a definição de funções dos cargos régios com alçada regional e local ${ }^{13}$. Neste último âmbito se insere a promulgação do regimento dos corregedores ${ }^{14}$ que dota o ofício de amplas atribuições fiscalizadoras do exercício do poder concelhio. Pela mesma altura, anos trinta e quarenta de Trezentos, é introduzida a figura dos vereadores e incrementada a nomeação de juízes de fora, interferindo-se, diretamente, no âmago da autonomia municipal ${ }^{15}$.

Uma citação de Carvalho Homem referente aos últimos vinte anos do reinado de Afonso IV é elucidativa quanto a esta conjuntura de aceleração de reformas legislativas e administrativas pelas quais a coroa tentava moldar, à sua feição, a cultura política. Para este autor, esse período consubstanciou "um momento-chave da construção institucional da nossa Idade Média tardia"16.

Regressemos às caraterísticas da ordem jurídica medieval, um dos ingredientes mais determinantes da cultura política. De acordo com os fundamentos do pensamento acerca da sociedade e do poder, todos os corpos sociais e políticos tinham uma existência complementar e necessária. E, para exercerem as funções específicas e indispensáveis ao todo, era imprescindível que lhes fosse concedido um certo grau de autonomia. A aplicação deste raciocínio às comunidades territoriais transcreve-se na capacidade de autogoverno e na competência legislativa limitada ${ }^{17}$. Esta era a teoria formulada ou aceite pelos letrados. E como seria recebida pelos concelhos portugueses em meados do século XIV?

Antes de mais, a categoria concelhos aplica-se a comunidades de complexidade muito variada, desde cidades, vilas a pequenas povoações. Nestas circunstâncias, atendendo à preparação do pessoal dirigente, existiriam graus de domínio diferenciados da ordem jurídica e, numa perspetiva mais global, de apropriação da cultura política.

Vários exemplos indiciam que qualquer agremiação territorial atingiria um limiar mínimo de literacia política. Com efeito, pequenas comunidades conquistavam o re-

${ }^{13}$ Cf. COELHO, Maria Helena da Cruz: "O poder e a sociedade no tempo de Afonso IV ...", pp. 41-42 e 46; HOMEM, Armando Luís de Carvalho: "Dionisius et Alfonsus, Dei Gratia Reges ...", pp. 19- 20; SOUSA, Bernardo Vasconcelos: D. Afonso IV ... pp. 73-79.

${ }^{14}$ Regimento que conheceu uma primeira versão em 1332, sendo depois revisto em 1340. Documentos publicados por Marcelo CAETANO: História da Administração Municipal de Lisboa na $1^{a}$ dinastia (11791383), Lisboa, Academia Portuguesa de História, 1981, $2^{\mathrm{a}}$ edição pp. 151-174.

${ }^{15}$ COELHO, M. Helena e MAGALHÃES, J. Romero: O poder concelhio das origens às cortes constituintes, Coimbra, Centro de Estudos e Formação Autárquica, 1986, pp. 9-13. CAETANO, Marcelo: História da Administração Municipal ... pp. 67-91; MORENO, H. Baquero: "A presença dos corregedores nos municípios e o conflito de competências (1332-1459)", in Revista de História, 9, Porto, (1989), pp. 77-88 (disponível em http://ler.letras.up.pt/uploads/ficheiros/6411.pdf, consultado a 2 de Junho).

${ }^{16}$ HOMEM, Armando Luís de Carvalho: "Dionisius et Alfonsus ...", p. 24. Cf. do mesmo autor "Estado Moderno e Legislação Régia: Produção e Compilação Legislativa em Portugal (séc. XIII-XIV)", in A Génese do Estado Moderno no Portugal Tardo-Medievo (Séculos XIII-XV). ... pp. 114-115.

${ }^{17}$ HESPANHA, António Manuel: História de Portugal Moderno. Político e Institucional, Lisboa, Universidade Aberta, 199, pp. 29/30 e 159/160. 
conhecimento da sua personalidade jurídica ${ }^{18}$ e outras, que em tempos foram dotadas de autonomia (ou que pretendiam vir a obtê-la), sabiam a importância da posse e preservação física dos documentos onde se consignavam foros e costumes, forais e outras cartas de privilégio e esgrimiam argumentos sustentados no relacionamento com a coroa ${ }^{19}$. Assim, o nível elementar de identidade de uma terra corresponderia à aceitação da sua existência autónoma pelas outras estruturas do sistema político.

No lado oposto da balança, contavam-se cidades e grandes vilas que se moviam habilmente nos meandros da cultura política ${ }^{20}$. Eram lideradas por governantes experimentados, dominando eles próprios a terminologia jurídica ou sendo assessorados por legistas que vertiam para linguagem letrada os propósitos locais. Para além deste pessoal político saber jogar com as virtualidades da ordem jurídica medieval, podia mesmo conceber um discurso estruturado sobre a própria comunidade que atualizava em momentos de diálogo com a coroa ${ }^{21}$. E a vontade expressa de agir no sistema político não é apenas visível na produção de discursos, manifestando-se, também, na ativação de processos de arquivo de documentos considerados relevantes ${ }^{22}$.

Em síntese, nos anos centrais do século XIV, encontram-se exemplos de concelhos, de dimensão política e económica variável que manejam na perfeição as "armas

${ }^{18}$ Caso dos moradores de Ribeira de Pena que solicitam a Afonso IV a sua constituição em concelho (MARQUES, José, “A origem do concelho de Ribeira de Pena (1331)", Revista de Guimarães, $\mathrm{n}^{\circ}$ 103, (1993), pp 327-341 (disponível em http://www.csarmento.uminho.pt/docs/ndat/rg/RG103_13.pdf, consultado a 13 de Junho de 2102).

${ }^{19}$ Caso de Rio Maior (testemunho do século XV), um aglomerado de pequena dimensão e personalidade jurídica indefinida, que demonstrou ter consciência dos seus direitos. Veja-se OLIVEIRA, Luís Filipe, "Entre a vila e a aldeia. A comunidade de Rio Maior na Idade Média", Arquipélago. História, $2^{\mathrm{a}}$ série, col. VIII, (2004), pp. 221-236 (disponível em http://repositorio.uac.pt/bitstream/10400.3/402/1/Luis_Oliveira_p221236.pdf, consultado a 13 de Junho de 2012).

${ }^{20}$ Ainda que, para o século XIV, esses indivíduos não sejam conhecidos, de forma minimamente sistemática, com exceção dos oficiais de Lisboa (Cf. FARELO, Mário: A oligarquia camarária de Lisboa: (1325-1433), Doutoramento em História, Especialidade em História Medieval, Lisboa, Faculdade de Letras da Universidade de Lisboa, 2009 - disponível em http://repositorio.ul.pt/handle/10451/569, consultado a 10 de Junho de 2012).

${ }^{21}$ Cf. a análise do discurso dos autarcas da cidade do Porto e de Elvas - COSTA. Adelaide Pereira Millán da: Projecção espacial de domínios. Das relações de poder ao burgo portuense, Doutoramento em História Medieval, Lisboa, Universidade Aberta, 1999, pp. 92-152; id.: "O discurso político dos homens do concelho portuense na época medieval", Discursos de Legitimação. Actas do Congresso, Lisboa, Universidade Aberta, (2003) (disponível em http://repositorioaberto.uab.pt/bitstream/10400.2/1554/1/ComACosta.htm, consultado a 30 de Junho de 2012); id., "O discurso político dos concelhos portugueses na Baixa Idade Média: convergências e especificidades - o caso de Elvas", Des(a)fiando discursos. Homenagem a Maria Emília Ricardo Marques, Lisboa, Universidade Aberta, (2005), pp. 265-272 (disponível em http://repositorioaberto.uab.pt/ bitstream/10400.2/359/1/Des\%28a\%29fiando\%20Discursos265-272.pdf.pdf consultado a 30 de Junho de 2012). Saliente-se que estas abordagens foram concretizadas com base em fontes existentes para o século XV.

${ }^{22}$ Cf. ROLDÃO, Ana Filipa: A memória urbana da cidade. A administração urbana e práticas de escrita em Évora (1415-1536), Doutoramento em História, Especialidade em História Medieval, Lisboa, Faculdade de Letras da Universidade de Lisboa, 2011 (disponível em http://repositorio.ul.pt/handle/10451/4858, consultado a 30 de Maio de 2012) 
jurídicas", sejam as cidades de Braga ${ }^{23}$ e Porto ${ }^{24}$, a vila de Setúbal ${ }^{25}$ ou Figueira, uma terra, nas palavras de José Marques, sem expressão demográfica nem peso político ${ }^{26}$. Existiria, assim, um substrato cultural partilhado pelas comunidades territoriais sobre as bases do seu agir político.

\section{A PROBLEMÁTICA, AS FONTES E OS PROTAGONISTAS}

Escrevi que o propósito deste artigo era o de apreender a cultura política em ação no âmbito do relacionamento estabelecido entre os concelhos e a coroa, no segundo e terceiro quarteis do século XIV, situando-o numa circunstância concreta: os momentos de realização de $\operatorname{cortes}^{27}$. Ficou assim estabelecida uma premissa que se torna necessário equacionar: as crenças sobre os fundamentos do poder e as normas sobre o seu exercício captam-se com base nas petições apresentadas pelos concelhos em contexto parlamentar e nas consequentes respostas dos monarcas. Trata-se de um pressuposto aparentemente arriscado. Senão vejamos.

Segundo Armindo de Sousa, os capítulos de $\operatorname{cortes}^{28}$ (o pedido e a resposta) constituem um "género literário especial, geralmente de tipo narrativo, mas também oratório e até dramático" 29 . Recuperemos a desmontagem da estrutura interna dos artigos

${ }^{23}$ MARQUES, José: “D. Afonso IV e as Jurisdições Senhoriais ...”; id., “O Senhorio de Braga, no século XV: principais documentos para o seu estudo", Bracara Augusta, vol. 46, Braga, 1997; COELHO, Maria Helena da Cruz: "O Arcebispo D. Gonçalo Pereira ..."; id.: "Bispos e reis: oposições em torno de bens e jurisdições temporais".

24 DUARTE, Luís Miguel: "Um burgo medieval que muda de senhor. Episódios da vida do Porto medievo", Ler História, no 5, Lisboa, (1985), pp. 3-16; SOUSA, Armindo de: "Tempos Medievais", História do Porto, dir. Luís A. de Oliveira RAMOS, Porto, Porto Editora, (1994), pp. 238-245; COSTA, Adelaide Pereira Millán da, "Comunidades urbanas de senhorio eclesiástico: a divergente experiência das cidades do Porto e de Braga", AAVV, Estudos em homenagem ao Professor Doutor José Marques, vol. I. Porto, Faculdade de Letras da Universidade do Porto, (2006), pp. 77-85 (disponível em http://ler.letras.up.pt/uploads/ficheiros/4799.pdf, consultado a 8 de Junho de 2012).

25 MARQUES, José: “A ordem de Santiago e o concelho de Setúbal em 1341”, As Ordens Militares em Portugal e no Sul da Europa, Lisboa, ed. Colibri, C. M. Palmela, (1997), pp. 285-305 (disponível em http:// ler.letras.up.pt/uploads/ficheiros/6352.pdf, consultado a 5 de Junho de 2012).

26 MARQUES, José, "O concelho alentejano de Figueira e a Ordem de Avis", Revista da Faculdade de Letras. História, (1988), vol. 5, pp. 95-112 (em linha http://ler.letras.up.pt/uploads/ficheiros/2104.pdf, consultado a 5 de Junho de 2012).

27 O tema das cortes medievais foi objeto de uma obra lapidar da autoria de Armindo de SOUSA (As Cortes Medievais Portuguesas (1385-1490), 2 vols., Porto, INIC/CHUP, 1990), a princípio recebida com algumas reservas mas que ainda hoje dita a ortodoxia de interpretação desta subestrutura do sistema político (DUARTE, Luís Miguel: “The Portuguese Parliament: are we asking the rigth questions?”, e-JPH, vol. 1, number 2, winter (2003), disponível em http:/www.brown.edu/Departments/Portuguese_Brazilian_Studies/ ejph/html/issue2/html/duarte_main.html, consultada a 4 de Maio de 2012).

${ }_{28}$ Sobre as formas diversas de nomear estes documentos veja-se SOUSA, Armindo: As Cortes Medievais ... I, pp. 477-478. Serão utilizados neste texto, de forma indiscriminada, os termos: artigos (que segundo o autor é a designação mais comum no século XIV), capítulos e agravamentos.

29 SOUSA, Armindo de: As Cortes Medievais ... I, p. 510. Para além da sua obra principal, a interpretação de Armindo se Sousa sobre os mecanismos de formulação dos capítulos gerais foram exemplificados nos trabalhos "O Discurso político dos concelhos nas cortes de 1385", Revista da Faculdade de Letras. História, $2^{\mathrm{a}}$ série, vol. 2, Porto, FLUP, (1985) (disponível em http://ler.letras.up.pt/uploads/ficheiros/1944.pdf, consultado 
gerais, proposta pelo autor: (i) factos motivadores dos requerimentos, (ii) justificações mais ou menos teóricas e (iii) requerimentos propriamente ditos. Armindo de Sousa defendeu que o núcleo substantivo do discurso centrava-se no requerimento, dado que aí se consignava aquilo que verdadeiramente os procuradores desejavam ver desembargado pelos monarcas; as outras duas partes eram "geralmente retórica ao serviço daquele desejo, adjunções apelativas destinadas a atrair a benevolência dos reinantes" ${ }^{30}$.

A minha proposta de trabalho é precisamente a de analisar as justificações aduzidas aos agravamentos apresentados no parlamento, aquilo que Armindo de Sousa reputaria de acessório para a apreensão dos valores dos povos. Sustento que é importante identificar em nome de quê se pede ou protesta e, do lado da coroa, se anui, rejeita ou protela uma resposta. Especificamente, opto por examinar a argumentação expressa num tipo documental que tem vindo a ser utilizado de modo profuso na historiografia medieval portuguesa, os capítulos especiais de cortes ${ }^{31}$.

a 2 de Maio de 2012) e "A estratégia política dos municípios no reinado de D. João II", Revista da Faculdade de Letras. História, $2^{\mathrm{a}}$ série, vol. 6, Porto, FLUP, (1989), pp. 137-174 (disponível em http://ler.letras.up.pt/ uploads/ficheiros/2141.pdf e consultado a 2 de Maio de 2012).

${ }^{30}$ SOUSA, Armindo de: As Cortes Medievais ... I, pp. 512-514.

${ }^{31}$ Seria moroso elencar toda a investigação portuguesa desenvolvida sobre a análise de capítulos de cortes em Portugal, desde há trinta anos a esta parte. Permitimo-nos destacar os seguintes trabalhos: ANDRADE, Amélia Aguiar; GOMES, Rita Costa: "As Cortes de 1481: uma abordagem preliminar", Estudos Medievais, $n^{\circ}$ s. 3/4, Porto, CEH, (1983/1984), pp. 151-212; COELHO, Maria Helena da Cruz: "As Cortes de Leiria e Leiria em Cortes", As Cortes e o Parlamento em Portugal. 750 anos das Cortes de Leiria de 1254. Actas do Congresso Internacional, Lisboa, 2006, pp. 21-37; id.: "A Guarda em cortes nos séculos XIV e XV", Revista Portuguesa de História, t. XXXV, (2001-2002), pp. 123-142 (disponível em https://estudogeral.sib.uc.pt/ bitstream/10316/12679/1/Maria\%20Helena\%20da\%20Cruz\%20Coelho\%2035.pdf, consultado a 13 de Maio de 2012); id.: O Concelho e Senhorio de Viseu em Cortes", Actas do Congresso "Infante D. Henrique, Viseu e os Descobrimentos", Viseu, 27-29 de Maio de 1993, Viseu, Câmara Municipal, (1995), pp. 83-112; id.: "O discurso de Guimarães em Cortes", Actas do $2^{\circ}$ Congresso Histórico de Guimarães, vol. 6, História Local, Guimarães, (1997), pp. 29-43; Id.: "Dos males aos remédios: o concelho em Cortes", in Montemor-o-velho a caminho da Corte e das Cortes, Montemor-o-Velho, Câmara Municipal de Montemor-o-Velho, 2010, pp. 25-39; id.: "Relações de domínio no Portugal concelhio de meados de Quatrocentos", in Revista Portuguesa de História, t. XXV, Coimbra, (1990), pp. 235-289; Id.: "As relações fronteiriças galaico-minhotas à luz das Cortes do século XV" Revista da Faculdade de Letras, II série, vol. VII, Porto, (1990), pp. 59-70; id.: "Riba Côa em Cortes (séc. XV)", Congresso Histórico Luso-Espanhol "O Tratado de Alcanices e a Importância Histórica das Terras de Riba Côa", Lisboa, Universidade Católica Editora, (1998), pp. 233-246; id.: "O Social: do vivido ao representado em Cortes", Actas dos $2^{\circ}$ S Cursos Internacionais de Verão de Cascais, vol. 2, Cascais, Câmara Municipal de Cascais, (1996), pp. 15-44; COELHO, Maria Helena da Cruz, RÊPAS, Luís Miguel: "Um cruzamento de fronteiras. O discurso dos Concelhos da Guarda em Cortes", iberografias, Lisboa, 9, (2007), p. 91-96; COELHO, Maria Helena da Cruz, RÊPAS, Luís Miguel: "As petições dos concelhos do distrito da Guarda em Cortes e a política transfronteiriça", Territórios e Culturas Ibéricas, Lisboa, (2005), pp. 131-141 (disponível em http://www.cei.pt/pdfdocs/As\%20peticoes.pdf, consultado a 15 de Maio de 2012); CUNHA, Maria Cristina e COSTA, Paula Pinto: "Bragança em cortes no final do século XV", As Cortes e o Parlamento em Portugal. 750 anos das cortes de Leiria de 1254. Actas do Congresso Internacional, Lisboa, Divisão de Edições da Assembleia da República, (2006), pp. 143-152; FARELO, Mário: "Lisboa nas Cortes da Primeira Dinastia (1254-1383)", As Cortes e o Parlamento em Portugal. 750 anos das cortes de Leiria de 1254. Actas do Congresso Internacional, Lisboa, Divisão de Edições da Assembleia da República, (2006), pp. 129-142: MORENO, Humberto Baquero: "O concelho de Beja nas Cortes de Santarém de 1451 após a sua clausura". Memória, 1, Lisboa, (1989), p. 267-278; id.: "Capítulos especiais de Ponte de Lima apresentados nas cortes de Coimbra de 1394", Bracara Augusta, Braga, vol. XXXV, nº. 79-80 (92-93), (1981, pp. 389-395; id.: "As cortes de Lisboa de 1448 (capítulos especiais de Évora)", in Bracara Augusta, Braga, vol. XXXVI, 
Após as veementes considerações de Armindo de Sousa sobre este género de petições, dir-se-ia que o risco de avançar com esta perspetiva de estudo aumenta. Recuperemos o seu pensamento: os artigos especiais "tiveram interesse e alcance local, apresentaram-se em cortes e fora delas, foram redigidos nas câmaras municipais e não nos parlamentos e, deferidos, não tiveram valor de ordenações mas de privilégios" ${ }^{\prime 2}$. Ou seja, a tentativa de encontrar nesta fonte esteios da cultura política, pressagia um fracasso. E, no entanto, sem pretender refutar a interpretação deste autor ${ }^{33}$, antes secundando-a, considero que o objetivo é concretizável.

Das fraquezas apontadas por Armindo de Sousa aos agravamentos especiais, apartando-os das espécies documentais dotadas de uma natureza parlamentar, podemos retirar a sua força para apreender a cultura política ativada em Portugal em meados do século XIV, entre a coroa e os concelhos.

Os artigos especiais escrevem-se localmente, não sendo refundidos ou redigidos em ambiente de cortes por especialistas de direito ${ }^{34}$. Assim, as condições em que são produzidos admitem ao investigador uma aproximação mais genuína às formas como os líderes de uma comunidade se movimentavam na cultura política. Estes documentos não se encontrariam contaminados com uma eventual sabedoria letrada alheia ${ }^{35}$. Clarificando: longe de se ensaiar aqui uma espécie de reabilitação desta fonte enquanto discurso parlamentar, explora-se a sua redação concelhia.

A premissa pela qual existia um vínculo direto entre os factos narrados nestes textos e aquilo que realmente aconteceu, há muito foi ultrapassada. Atualmente parte-se para a sua análise com as reticências próprias de quem lhes reconhece uma tendência para a hiperbolização da realidade. Assim, são já vários os autores que exploram a sua dimensão argumentativa ${ }^{36}$. Se todos estaremos de acordo quanto à menor complexi-

$\mathrm{n}^{\mathrm{o}} \mathrm{s} .81-82$ (94-95), (1982), pp. 323-344; id.: "A representação do concelho de Guimarães nas cortes de Lisboa de 1446", Revista da Faculdade de Letras. História, II ${ }^{\mathrm{a}}$ Série, vol. I, Porto, (1984), pp. 411-415; id.: "A representação do concelho de Caminha junto do poder central em meados do século XV", Revista da Faculdade de Letras. História, $2^{\mathrm{a}}$ série, 6, Porto, (1989), p. 95-104; ROCHA, Filomena Raquel Guerra dos Reis Teles da: O Porto e o poder central na segunda metade do século XV (estudo e publicação dos capítulos especiais da cidade, Dissertação de Mestrado em História Medieval apresentada à Faculdade de Letras do Porto, Porto, 1996; SILVA, Filomeno Amaro Soares da: O Porto em Cortes (1331-1406), dissertação de Mestrado em História Medieval, Porto, Faculdade de Letras da Universidade do Porto, 1999 (disponível em http://dited. bn.pt/30867/1854/2311.pdf, consultado a 10 de Maio de 2012); SILVA, Manuela Santos: "O concelho de Óbidos nas Cortes Medievais Portuguesas", A região de Óbidos na Época Medieval. Estudos. col. P. H. - Estudos e Documentos, Caldas da Rainha, 1994, pp. 73-84; VIANA, Mário, "A participação do concelho de Santarém em cortes nos séculos XIV e XV”, ARQUIPÉLAGO • HISTÓRIA, 2a série, VIII, (2004), pp. 309-392 (edição dos capítulos especiais de Santarém) (disponível em http://repositorio.uac.pt/bitstream/10400.3/407/1/ Mario_Viana_p311-391.pdf, consultado a 10 de Maio de 2012).

${ }^{32}$ SOUSA, Armindo: As Cortes Medievais ... I, p. 476 e, também, pp. 488-495.

${ }^{33}$ DUARTE, Luís Miguel: "The Portuguese Parliament ...".

${ }^{34}$ SOUSA, Armindo de: As Cortes Medievais ..., I, p. 496

${ }^{35}$ Sobre o aproveitamento dos capítulos especiais de cortes e a sua relação com os centrais, cf. COELHO, Maria Helena da Cruz: "O Discurso de Guimarães ...", pp. 31-32.

${ }^{36}$ COELHO, Maria Helena da Cruz: "Riba Côa em Cortes ...", p. 235); id.: "O poder concelhio em tempos medievais: o «deve» e «haver» historiográfico", Revista da Faculdade de Letras. História, $3^{\mathrm{a}}$ série, vol. 7, Porto, (2006), p. 26 (disponível em http://ler.letras.up.pt/uploads/ficheiros/3401.pdf, consultado a 12 de Maio); id.: "O discurso de Guimarães... ", pp. 29, 31-32; id.: "A Guarda em cortes nos séculos XIV e XV...", pp. 126-127. Veja-se a exaustiva análise da argumentação utilizada nos capítulos especiais dos concelhos 
dade e elaboração dos fundamentos dos capítulos especiais face aos gerais ${ }^{37}$, parece desenhar-se um consenso quanto à viabilidade do exame deste tipo de agravamentos enquanto género literário ${ }^{38}$.

Sustentando-se a intenção persuasiva expressa nos artigos de cortes em grande medida nas justificações, defendo que essa parte da estrutura interna dos textos corresponde a um domínio onde se poderá perscrutar a apropriação da cultura política por parte dos diferentes concelhos. E defendo ainda que essas alegações têm um peso não minimizável no que Armindo de Sousa consideraria "a eficácia do discurso dos povos". Assim, quando a argumentação se escudava em fontes de direito, se não influenciava, de forma decisiva, o sentido da decisão régia, pelo menos implicaria que ela fosse mais sustentada. Mormente quando existiam provas físicas das normas jurídicas alegadas; se estas eram aceites na resolução de pleitos em sede de tribunal, sê-lo-iam também em sede parlamentar.

Em síntese, reafirma-se que o primeiro objetivo deste artigo é o de identificar se a argumentação veiculada nos capítulos especiais, conhecidos entre 1325 e 1361, corresponde a um veículo para o conhecimento da apropriação concelhia ${ }^{39}$ da cultura política. E a escolha cronológica não é inócua, dado que se trata de um tempo curto mas repleto de inovações do ponto de vista institucional.

Especificando, analisam-se os agravamentos especiais apresentados nas cortes realizadas nos reinados de Afonso IV (em Évora, Santarém ${ }^{40}$ e Lisboa, respetivamente em 1325, 1331 e 1352) e Pedro I (em Elvas, no ano de 1361 ${ }^{41}$ ). Ou melhor, examinam-se os artigos que permaneceram. Com efeito, não se poderia terminar um parágrafo sobre documentos sem mencionar a ressalva que é tão própria dos medievalistas que se transformou num lugar-comum: matizemos a representatividade das fontes conhecidas.

A percentagem de capítulos especiais remanescentes face aos que eventualmente terão existido não é mensurável. Como exemplo, basta pensar no acréscimo de pre-

raianos em Quatrocentos, cf. MARTINS, Rui Cunha: A fronteira antes da sua metáfora. Cinco teses sobre a fronteira hispano-portuguesa no século XV, Coimbra, 1 vol. 2000, pp. 149-235 e, ainda, COSTA, Adelaide Millán: "O discurso político dos homens do concelho portuense ..."; id.: "O discurso político dos concelhos portugueses na Baixa Idade Média: convergências e especificidades - o caso de Elvas ...".

${ }^{37}$ Escreve Maria Helena da Cruz COELHO: "Nos capítulos especiais de Guimarães não se descobre uma filosofia argumentativa muito elaborada, como também os soberanos não se preocuparam, demasiadamente, em fundamentar as suas respostas. Houve a intenção de um objectivo pedir e um estrito deliberar" ("O discurso de Guimarães ...", p. 43).

${ }^{38}$ Tal não significa que se rejeitem as significativas informações sobre a vida local transmitida por estas fontes, aos níveis económico, financeiro, político, jurisdicional e, mesmo mental, mas que se impõe a sua consideração enquanto discurso comprometido.

${ }^{39}$ No sentido de apropriação das oligarquias do concelho.

${ }^{40}$ Realizou-se outra assembleia em Santarém, em 1340, da qual nos ficaram importantes documentos mas não capítulos de cortes. Contudo, há referência indireta à existência de 16 agravamentos especiais de Évora (Cf. ROLDÃO, Ana Filipa: A memória urbana da cidade ... p. 205).

${ }^{41}$ Documentação publicada em Cortes Portuguesas: Reinado de D. Afonso IV: (1325-1357) / Lisboa, Instituto Nacional de Investigação Científica/Centro de Estudos Históricos da Universidade Nova de Lisboa, 1982 (doravante designado por Cortes de Afonso IV) e Cortes Portuguesas: Reinado de D. Pedro I, Lisboa, Instituto Nacional de Investigação Científica/Centro de Estudos Históricos da Universidade Nova, 1986 (doravante designado por Cortes de D. Pedro I). 
senças em reuniões de cortes por parte de Bragança, identificadas após a pesquisa feita nos documentos existentes no arquivo distrital de Bragança ${ }^{42}$; ou o aumento de capítulos de cortes resultantes do estudo do inventário da câmara de Évora, realizado cerca de $1415^{43}$. Os testemunhos que têm vindo a ser descobertos e, assumindo o enunciado de Ana Filipa Roldão, os "documentos imateriais" ${ }^{44}$ multiplicam as fontes disponíveis.

Aclarada a problemática, os objetivos da sondagem proposta e as fontes do diálogo institucional, impõe-se determo-nos nos protagonistas: os concelhos que foram autores das petições investigadas. Para tanto, recorre-se a um mapeamento anacrónico do seu estatuto político, por testemunho elaborado cerca de 120 a 150 anos depois. Explicitemos. Trata-se de uma representação do espaço cénico onde as sessões inaugurais de cortes se realizavam ${ }^{45}$, com a posição relativa ocupada na cerimónia por todos os representantes dos concelhos que tinham assento em bancos ${ }^{46}$. Das precedências das cidades e vilas nesse ato solene, infere-se a sua posição simbólica no sistema político ${ }^{47}$.

Com base neste anacronismo analítico e conscientes dele, conclui-se que, dos onze concelhos para os quais existem dados ${ }^{48}$, cinco ocupam ou virão a ocupar o $1^{\circ}$ banco de cortes $\left(\right.$ Porto $^{49}$, Evora $^{50}$, Lisboa $^{51}$, Coimbra $^{52}$ e Santarém $\left.^{53}\right)$, dois o $2^{\circ}\left(\right.$ Lamego $^{54} \mathrm{e}$

${ }^{42}$ CUNHA, Maria Cristina e COSTA, Paula Pinto: "Bragança em cortes no final do século XV ...", p.. 146.

${ }^{43}$ ROLDÃO, Ana Filipa: A memória urbana da cidade ..., pp. 198-207.

${ }^{44}$ Id.: ibid., pp. 181 e ss.

${ }^{45}$ Desconhece-se o início sua vigência desta organização do espaço. Luís Miguel DUARTE, questionando a representatividade da hierarquização de concelhos a partir dos bancos, afirma que os locais de assento de 1481 podem ter sido obtidos um ou dois séculos antes, "The Portuguese Parliament ...".

46 Trata-se de 80 quando, para o século XV, Armindo de Sousa conta cerca de 130 concelhos que estão presentes.

${ }^{47}$ SOUSA, Armindo: As cortes medievais ..., I, pp. 190-194.

${ }^{48}$ Conta-se ainda um capítulo especial do julgado de Refoios que não iremos utilizar na análise

49 SOUSA, Armindo: “Tempos Medievais", História do Porto, dir. Luís A. de Oliveira RAMOS, Porto, Porto Editora, 1994, pp. 119-253.

50 BEIRANTE, Maria Ângela: Évora na Idade Média, Lisboa, Fundação Calouste Gulbenkian/JNICT, 1995; id.: "O Alentejo na 2a metade do século XIV - Évora na crise de 1383-1385", Estudos Medievais, n” 7 , Porto, CEH, (1986), pp. 119-154.

${ }^{51}$ Lisboa Medieval. Os rostos da Cidade, ed. KRUS, Luis; OLIVEIRA, Luís Filipe; FONTES, João Luís, Lisboa, Livros Horizonte, 2007; ANDRADE, Amélia Aguiar: "La dimensión urbana de un espacio atlântico: Lisboa" XXXIII Semana de Estudios Medievales. Estella, 17 a 21 de júlio de 2006, Pampluna, Gobierno de Navarra, (2007), p. 347-375; MARTINS, Miguel, "O concelho de Lisboa durante a Idade Média. Homens e organização municipal”, Cadernos do Arquivo Municipal de Lisboa, Lisboa, Câmara Municipal de Lisboa, 7 , (2005), pp. 64-110.

${ }^{52}$ COELHO, Maria Helena da Cruz: "Coimbra em tempos medievais (Séculos XIV-XV)", A História Tal Qual se Faz, coord. de José d'Encarnação, Lisboa, Edições Colibri-Faculdade de Letras da Universidade de Coimbra, (2003), pp. 65-78; id.:, "Coimbra Trecentista. A Cidade e o Estudo", Biblos, LXVIII, Coimbra, (1992), pp. 335-356; id.: "O infante D. Pedro, duque de Coimbra", Biblos, LXIX, Coimbra, (1993), pp. 115-157.

${ }^{53}$ BEIRANTE, Maria Ângela: Santarém medieval, Lisboa, Faculdade de Ciências Sociais e Humanas da Universidade Nova de Lisboa, 1980; VIANA, Mário: Espaço e povoamento numa vila portuguesa (Santarém, 1147-1350), Lisboa, Caleidoscópio, 2007; COELHO, Maria Helena da Cruz: "Estudo", Foral de D. Manuel a Santarém, Santarém, Câmara Municipal, 2007, pp. 9-28.

54 SARAIVA, Anísio: "A inserção urbana das catedrais medievais portuguesas: o caso da catedral de Lamego", Catedral y ciudad medieval en la Península Ibérica. Eds. Eduardo Carrero y Da- 
Silves $\left.{ }^{55}\right)$, um o $4^{\circ}\left(\right.$ Bragança $\left.^{56}\right)$, um o $5^{\circ}\left(\right.$ Montemor-o-Velho $\left.^{57}\right)$, e dois o $6^{\circ}\left(\right.$ Sintra $^{58}$ e Torres Novas ${ }^{59}$ ). Ou seja, sendo os bancos dezasseis, os concelhos para os quais possuímos informação sobre capítulos especiais neste período, situam-se quer na liderança política da futura (ou já presente) representação dos povos em cortes, quer numa posição hierarquicamente confortável.

\section{OS ARGUMENTOS CONCELHIOS E A APROPRIAÇÃO DA CULTURA POLÍTICA}

O ponto de partida da análise corresponde a um total de duzentos e noventa e dois artigos especiais apresentados pelos concelhos antes identificados, nas assembleias ocorridas em 1325, 1331, 1352 e $1361^{60}$. Como premissa da abordagem, optou-se por considerar de forma articulada, e não em fases autónomas, as petições e as respostas régias.

Com base na divisão da estrutura destes textos delineada por Armindo de Sousa ${ }^{61}$, conclui-se que noventa e cinco capítulos não adiantam qualquer sustentáculo argumentativo mas apenas manifestam os factos motivadores e o requerimento ${ }^{62}$. Examinada a matéria destes agravamentos, conclui-se pela inexistência de uma discrepância substantiva face a outros que incluem alegações explícitas.

niel Rico, Múrcia: Nausícaä, (2004), pp. 243-280 (disponível em http://coimbra.academia.edu/ SOUSASARAIVAAn\%C3\%ADsioMiguelde/Papers/261329/A_insercao_urbana_das_catedrais_medievais_ portuguesas_o_caso_da_catedral_de_Lamego, consultado a 9 de Maio de 2012).

${ }_{55}$ BOTÃ O, Maria de Fátima: Silves capital de um reino medievo, Silves, Câmara Municipal de Silves, 1992; Id.: "Algumas considerações sobre conflitos e práticas de cidadania, em Silves medieval", Os reinos ibéricos na Idade Média. Livro de Homenagem ao Professor Doutor Humberto Baquero Moreno, coord. FONSECA, Luís de; AMARAL, Luís Carlos; SANTOS, Maria Fernanda Ferreira, Porto, Faculdade de Letras da Universidade do Porto, (2003), vol. 2, pp. 1027-1034.

${ }^{56}$ COSTA, Paula Pinto da: "Bragança medieval no contexto transmontano", Brigantia, Bragança, vol. XXIV-XXV, n ${ }^{\circ} 1 / 4,(2004 / 2005)$, pp. 47-58.

${ }^{57}$ COELHO, Maria Helena da Cruz: Montemor-o-velho a caminho da Corte e das Cortes, Montemor-o-Velho, Câmara Municipal de Montemor-o-Velho, 2010; id.: "A origem do poder concelhio e o enquadramento do foral de Montemor", in Montemor-o-Velho. 20 anos do Poder Local, Montemor-o-Velho, Câmara Municipal, (1997), pp. 65-71; id.: "Os fundamentos do município de Montemor-o-Velho", in Forais de Montemor-o-Velho, Montemor-o-Velho, Câmara Municipal de Montemor-o-Velho, 2002, pp. 9-39.

${ }^{58}$ CARVALHO, Sérgio Luís de: Sintra na Idade Média, Sintra Editora, 1992.

${ }^{59}$ CONDE, Manuel Sílvio Alves: Uma paisagem humanizada. O Médio Tejo nos Finais da Idade Média, Cascais, 2 vols. Patrimonia Historica, 2000; COELHO, Maria Helena da Cruz: "O concelho de Torres Novas em tempos de crescimento e consolidação de um reino", Nova Augusta, n. 6, Especial, (1992), pp. 55-67.

${ }^{60}$ De seguida, elenca-se o número de capítulos especiais apresentado em cada reunião de cortes por concelho: Bragança (5 capítulos em 1331); Coimbra (23 capítulos em 1331 e 39 em 1361); Évora (10 capítulos em 1361); Lamego (25 capítulos em 1352); Lisboa (80 capítulos em 1331 e 4 em 1361); Montemor -o - Velho (6 capítulos em 1361); Porto (17 capítulos em 1331 e 16 em 1361); Santarém (12 capítulos em 1325 e 18 em 1331); Sintra (21 capítulos em 1331); Silves (7 capítulos em 1361); Torres Novas (9 capítulos em 1361).

${ }^{61}$ Confirme-se infra. Esta estrutura, apontada para os capítulos gerais encontra-se presente também nos capítulos especiais

${ }^{62}$ Para o período de 1385 a 1490, também Armindo de Sousa apontou a ausência, em alguns capítulos gerais, quer das justificações quer dos factos motivadores; contudo, não apresentou estimativas da percentagem de artigos em que tal ocorria (As cortes medievais ... I, p. 512). 
Parece abusivo assumir que a enunciação de um pedido não escorado em justificações corresponda sempre a um sintoma de fragilidade nos alicerces para o fundamentar. Assim vejamos.

Antes de mais, tem de equacionar-se a eventualidade do extravio, durante o processo de transcrição ou sumarização que deles faz o discurso régio, de partes de texto que se encontrariam consignadas nos originais dos capítulos. Por outro lado, as razões podiam ser tão óbvias que nem sequer se julgava necessário declará-las. Com efeito, em alguns artigos pressente-se a vigência de uma norma não expressa, pelo incumprimento da qual uma determinada situação se torna irregular.

Admitindo, no plano teórico, que a inexistência de argumentos resultava de falta de preparação dos redatores, seria viável conjugar este facto com o estatuto político dos concelhos que os apresentavam. Assim, as cidades e vilas cujos procuradores tinham assento nos $1^{\circ} \mathrm{S}$ e $2^{\circ} \mathrm{s}$ bancos de cortes escudariam os seus protestos em alegações, ao contrário das comunidades territoriais de menor importância. Trata-se, contudo, de uma hipótese que deve ser afastada, uma vez que todos os concelhos, nestas quatro assembleias, recorrem este tipo de formulação.

Também o fator cronológico é equacionável. Especifiquemos. Tratando-se dos primeiros textos deste género literário especial, não estaria ainda estabelecida uma depuração do discurso detetável em épocas posteriores. Tal asserção seria razoável se muitos artigos do século XV não fossem em tudo semelhantes aos que se encontram em análise, ao nível da simplicidade da formulação.

Apesar de não existir uma tipicidade própria nestes agravamentos, parecem desenhar-se algumas linhas interpretativas. As mais das vezes, trata-se de situações anómalas, sobretudo atribuídas a oficiais régios mas também a senhores (nobres ou eclesiásticos) e a judeus. Dificilmente todos os casos de más práticas, conluio, desrespeito, prepotência, corrupção ou sobreposição de competências poderiam estar previamente contemplados na normativa jurídica local. Para isso apontam as respostas régias a estes pedidos, no cômputo das quais a remissão para o costume ou foro da terra é residual ${ }^{63}$. Alguns destes requerimentos são objeto de despacho régio pontual, outros reformulam-se e consignam-se nos capítulos gerais. Noutros casos, os problemas não se traduzem em práticas consideradas gravosas pelo concelho mas em fenómenos únicos que, como tal, nunca poderiam encontrar-se enquadrados por normas jurídicas. É o que acontece com vários capítulos da cidade do Porto ${ }^{64}$.

A análise articulada entre petições e respostas régias permite concluir pela existência de um ritmo diferente de apropriação da ordem jurídica entre a coroa e os concelhos. Com efeito, são apresentados capítulos especiais sem incluírem qualquer tipo de justificação sobre temas que previamente tinham sido objeto de normalização régia, através de ordenações ou de artigos gerais ${ }^{65}$.

${ }^{63}$ Existem apenas oito ocorrências, em capítulos apresentados nas cortes de 1331, nomeadamente: capítulos de Lisboa n ${ }^{\circ}$ s 16, 17, 19, 74 e 75 (Cortes de D. Afonso IV, pp. 66, 67 e 83); capítulo n 17 do Porto (ibid., p. 89) e capítulos no s 3 e 12 de Santarém (ibid., pp. 91-94).

${ }^{64}$ Caso, por exemplo, dos capítulos apresentados nas cortes de $1331, \mathrm{n}^{\circ} \mathrm{s} 6$, 7, e 8 (Cortes de D. Afonso IV, p. 87).

${ }^{65}$ Vejam-se os capítulos apresentados nas cortes de 1331 por Coimbra, ${ }^{\circ}$ s 5,10 e 23 (Cortes de D. Afonso $I V$, pp. 58, 59 e 62) e por Santarém, $\mathrm{n}^{\circ} 11$ (ibid., p. 93); os capítulos $\mathrm{n}^{\circ} \mathrm{s} 7$ e 12 apresentados por Lamego em 
Vejamos, agora, os agravamentos que apresentam sustentação argumentativa. É inevitável atualizar as considerações expressas por Armindo de Sousa sobre esta parte da estrutura dos capítulos de cortes, ainda que o autor não tenha desenvolvido muito tal perspetiva nos seus trabalhos publicados ${ }^{66}$. Armindo de Sousa estabelece o que poderíamos denominar, de acordo com as categorias norteadoras deste texto, uma repercussão direta entre as alegações utilizadas pelos povos nos documentos produzidos em âmbito parlamentar e o domínio da cultura política. Assim, valoriza o saber técnico presente na redação dos artigos gerais, defendendo que esse processo era assistido e orientado por legistas e letrados. Afirma, ainda, que, enquanto forma de persuasão, os fundamentos se iam buscar, sobretudo, à esfera do direito e da justiça ${ }^{67}$.

Para ensaiar uma tipologia da argumentação presente nos capítulos especiais, nada melhor do que apoiarmo-nos em esquemas coevos de organização do pensamento. Explorando os capítulos gerais apresentados na assembleia de 1331, conclui-se que quem os sistematizou tinha uma ideia clara acerca das razões pelas quais os povos se agravavam, nomeando os seguintes tipos de situações irregulares: (i) as que contrariavam foros e costumes ${ }^{68}$, (ii) as causadoras de "grande dano e grande estrago" ${ }^{69} \mathrm{e}$, por último, (iii) as que punham em causa "o bom vereamento da terra e a prol comunal"70. Desta ordenação trecentista depreende-se uma destrinça entre justificações substantivas (a normativa local) e duas classes mais fluídas de motivos.

Na mesma linha, mas optando por uma formulação pela positiva, distinguir-se-á, entre a defesa (i) de valores morais e políticos, (ii) da ordem das coisas e (iii) da ordem jurídica. Para tanto, foi considerada a dialética estabelecida entre os fundamentos expressos na petição e na resposta régia (quando os havia).

Estou consciente de que uma proposta de arrumação dos capítulos de cortes em função do tipo de alegações aduzidas ao requerimento apresenta algumas fragilidades e arestas não completamente limadas. Antes de mais, ressalve-se que o mero reconhecimento de um enunciado ao qual é atribuído o estatuto de fundamentação não tem repercussões diretas no conteúdo do agravamento (ou vice-versa); assim, a argumentação não é em si um veículo para categorizar os temas dos artigos especiais.

Comecemos por analisar a categoria "Defesa de valores morais e políticos".

Nove capítulos recorrem ao critério básico de avaliação do comportamento dos indivíduos face a qualquer sistema de valores, limitando-se a declarar a lacónica expressão "como não deve ou como não é theudo" "11. Nestas circunstâncias, é impossível classificar esta expressão com mais pormenor, uma vez que ela tanto pode

1352 (ibid., pp. 142-145). Quanto às cortes de 1361, vejam-se os capítulos n 9 de Évora (Cortes de D. Pedro I, p. 99) e n ${ }^{\circ} 6$ de Torres Novas (ibid., pp. 125-126).

${ }^{66}$ SOUSA, Armindo: "Estado e Comunidade: Representação e Resistências", A Génese do Estado Moderno no Portugal Tardo-Medievo (Séculos XIII-XV). Ciclo temático de conferências organizado pela Universidade Autónoma de Lisboa no ano lectivo de 1996/97, coord. de Maria Helena da Cruz Coelho e Armando Luís de Carvalho Homem, Lisboa, UAL, (1999), pp. 311-312.

${ }^{67}$ As cortes medievais ... I, pp. 495-496.

${ }^{68}$ Veja-se o capítulo n ${ }^{\circ} 1$ (Cortes de D. Afonso IV, p. 27).

${ }^{69}$ Veja-se o capítulo ${ }^{\circ} 21$ (ibid., p. 34).

${ }^{70}$ Veja-se o capítulo ${ }^{\circ} 42$ (ibid., p. 42).

${ }^{71}$ Capítulos especiais apresentados às cortes de 1331: $\mathrm{n}^{\mathrm{o}} \mathrm{s} 5 \mathrm{e} 13$ de Coimbra (Cortes de D. Afonso IV, pp. 58, 60); ns 7, 13, 14, 21, 24, 52 de Lisboa (ibid., pp. 65, 66, 68, 69 e 77) e n 3 de Santarém (ibid., pp. 91-92). 
remeter para um julgamento de carácter moral quanto para o incumprimento de uma norma jurídica ou prática ${ }^{72}$. A linha que separa os capítulos sem argumentação do grupo agora considerado é muito ténue, se é que existe, podendo resultar apenas de contingências discursivas, como sejam o estilo de linguagem do redator. A apoiar esta asserção, refira-se que destas nove menções seis aparecem nos capítulos de Lisboa, apresentados na assembleia de 1331.

Dez artigos baseiam-se em justificações que remetem, claramente, para a simbiose entre a moral e a política, a razão e o direito. Enunciam-se aqui todas as formulações encontradas. Antes de mais: "sem razão"73, "sem razão e contra humanidade"74, "desonesto e sem razão"75, "sem direito e sem razão"76, "contra direito" 77 , "contra direito e justiça" "78. Acrescem a estas, outros tópicos genéricos referentes ao governo dos homens: "o comum da cidade" "79 o "serviço do rei e prol da cidade" 80 e o "serviço de Deus, do rei e prol da terra" $"$. Fazendo convergir os fundamentos do poder régio expressos pela coroa ${ }^{82}$ com esta argumentação dos povos, dir-se-ia que estes capítulos de cortes apenas acolhem o apelo ao bem comum e à moral. De referir que sete destes dez motivos são apresentados por Coimbra em 1361, o que deverá ser equacionado com a preparação técnica de um redator específico. Para além do mais, as outras alegações incluídas neste grupo são apenas utilizadas por Lamego e Santarém. Tendo consciência que o universo de análise é por demais reduzido, o panorama indicia, contudo, que as fundamentações mais genéricas e escudadas nos altos valores da razão e do direito seriam recurso empregue, preferencialmente, por concelhos bem situados na hierarquia política simbólica. Claro que só com uma pesquisa mais alargada, será possível confirmar ou infirmar esta hipótese.

Por fim, entre as razões genéricas baseadas em julgamentos de caráter ético, contam-se as seguintes: para o concelho é "mui grave e mui danoso" vos "escândalo grande" 84 , grande "escândalo e lhes iam contra sua honra" ${ }^{85}$ ou eram embargados "maliciosamente"

Abordemos, agora, a categoria "Defesa da ordem das coisas". A leitura dos capítulos de cortes permite afirmar que o conservadorismo, entendido como a limi-

72 Vejam-se, por exemplo os capítulos apresentados nas cortes de 1331: nº 7 e 24 de Lisboa (Cortes de D. Afonso IV, pp. 65, 68-79) e n 3 de Santarém, (ibid., pp. 91-92).

${ }^{73}$ Capítulos 8 e 15 de Coimbra apresentado nas cortes 1361 (Cortes de D. Pedro I, pp. 82, 84).

74 Capítulo 9 de Coimbra apresentado nas cortes 1361 (ibid., p. 82).

75 Capítulo 7 de Coimbra apresentado nas cortes 1361 (ibid., pp. 81-82).

76 Capítulo 24 de Coimbra apresentado nas cortes 1361 (ibid., pp. 87-88).

77 Capítulo $2^{\circ}$ do $2^{\circ}$ documento de Coimbra apresentado nas cortes 1361 (ibid., p. 93).

78 Capítulo 23 de Lamego apresentado nas cortes de 1352 (Cortes de D. Afonso IV, pp. 147-148); Capítulo 5 do $2^{\circ}$ documento de Coimbra apresentado nas cortes 1361 (Cortes de D. Pedro I, p. 94).

79 Capítulo 13 de Coimbra apresentado nas cortes 1361 (ibid., p. 84).

${ }^{80}$ Capítulo 11 de Coimbra apresentado nas cortes de 1361 (ibid., p. 83).

${ }^{81}$ Capítulo 2 de Santarém apresentado nas cortes de 1331 (Cortes de D. Afonso IV, p. 91).

82 Nomeadamente os formulados nos preâmbulos da legislação. Veja-se infra.

${ }^{83}$ Capítulo 18 de Coimbra apresentado nas cortes 1361 (Cortes de D. Pedro I, p. 85).

${ }^{84}$ Capítulo 1 do $2^{\circ}$ documento do Porto apresentado nas cortes 1361 (ibid., pp. 108-109).

85 Capítulo 3 de Évora apresentado nas cortes 1361 (ibid., p. 97).

${ }^{86}$ Capítulo 12 de Coimbra apresentado nas cortes de 1331 (Cortes de D. Afonso IV, p. 60). 
nar rejeição da mudança ${ }^{87}$, integrava a cultura política, definida como o repositório de valores e de práticas aceites pelos vários elementos atuantes no sistema político. Trata-se de um grupo abrangente, ainda que, as mais das vezes, se consubstancie num enunciado recriminador: a inovação. Enunciado este que justifica sessenta e um artigos especiais ${ }^{88}$.

Esta fundamentação, traduzida em expressões como "nunca foi senão ora", "ora novamente" ou "soia ser", aplica-se na sequência do relato da introdução de alterações em práticas que o tempo cristalizou. Por vezes, tratar-se-á de um hábito, de uma rotina anterior ${ }^{89}$ cuja transformação é reputada de irregular; noutras, presume-se a existência de uma norma de direito que sustenta o protesto ${ }^{90}$.

Face ao total das ocorrências, são dadas trinta e seis respostas que se limitam a ordenar quer a observância do costume quer a clarificação do mesmo ou, ainda, a indagar sobre a antiguidade da prática alegada. Outras decisões régias apelam ao direito, entendido como critério norteador de julgamento da situação ("como é direito") ou, de forma explícita, traduzido em normas de direito positivo. Assim, a análise articulada dos pedidos e das respostas indicia que nem sempre a normativa se encontrava consignada por escrito.

Ainda na categoria "Defesa da ordem das coisas" integra-se o repúdio por inovações que se traduzem na interferência drástica no status quo, na perspetiva do concelho que protesta. Trata-se quer de cartas régias, incorporando a concessão de mercês a determinados grupos de indivíduos ou a cidades e vilas, quer de posturas emitidas por outros núcleos urbanos, consideradas lesivas pelo peticionário ${ }^{91}$.

Abandonemos as justificações abstratas como o direito, a justiça, a razão, o dano, o prol comum ou a inovação e passemos à aparente solidez da ordem jurídica, enquanto escudo que sustenta os pedidos.

Neste âmbito, o núcleo argumentativo mais numeroso - presente em setenta e sete capítulos - refere-se às regras de direito de aplicação local, reunindo a invocação de fontes diferenciadas como o costume, os foros e costumes e os forais ${ }^{92}$. Somam-se aos quantitativos anteriores dezanove petições que se fundamentam em diplomas também integráveis na ordem jurídica local mas que são autonomizados nos pedidos:

87 Com exceções, como adiante veremos.

${ }^{88}$ Este argumento não estará acantonado aos protestos de meados do século XIV, dado que ele é reiterado na documentação de cortes do século XV. Cf. COSTA. Adelaide Pereira Millán da: Projecção espacial de domínios ... pp. 72-73; id.: "O discurso político dos homens do concelho portuense..."; id.: "O discurso político dos concelhos portugueses na Baixa Idade Média ...".

${ }^{89}$ Veja-se, a título de exemplo o artigo n ${ }^{\circ} 4$ apresentado por Santarém nas cortes de 1325 (Cortes de D. Afonso $I V$, p. 4).

${ }^{90}$ Por exemplo, nos capítulos de Lisboa de 1331 ( $\mathrm{n}^{\mathrm{o}} \mathrm{s}$ 1, 2, 3, 7, 9 e 10, entre outros) descrevem-se realidades anómalas como a sobreposição de jurisdições entre oficiais régios e concelhios sem recorrer a uma argumentação sustentada no direito (Cortes de D. Afonso IV, pp. 63-65).

91 Uma pequena classe de justificações escapa aos grupos delineados para integrar os fundamentos dos capítulos especiais de cortes do período em análise. Trata-se de três artigos em que se adianta como mote a analogia com circunstâncias que ocorrem noutras comunidades territoriais. São eles: capítulo $\mathrm{n}^{\circ} 3$ de Lamego apresentado nas cortes de 1352 (Cortes de D. Afonso IV, p. 140); capítulos 4 e 8 de Torres Novas apresentados nas cortes de 1361 (ibid., pp. 123-124 126-127).

92 Apenas no capítulo 25 apresentado por Lisboa em 1331 se refere, para além destas fontes de direito, uma postura e costume concelhios (Cortes de D. Afonso IV, p. 69) 
trata-se de mercês, defesas, mandados e privilégios régios atribuídos à comunidade territorial específica que com eles acena em cortes $^{93}$.

Por último, é irrisória a fundamentação dos agravamentos em leis régias. De forma explícita, apenas um artigo de Lisboa refere uma lei e, de forma implícita, contam-se mais três ocorrências, vindas de Lamego e do Porto ${ }^{94}$.

As normas de direito de aplicação local não se utilizam nos artigos de cortes de forma linear e inequívoca; pelo contrário, tanto no pedido do concelho quanto na resposta régia, verifica-se alguma permeabilidade no seu recurso. Assim, vejamos.

A clássica definição de foros e costumes feita pelos especialistas ${ }^{95}$ e a consequente distinção face aos forais, não terá presidido às justificações incorporadas nos artigos especiais de cortes, de meados do século XIV. Com efeito, cimenta-se a hipótese, já adiantada a propósito das respostas régias atribuídas às alegações sustentadas na inovação, de que nem sempre o recurso ao fundamento do costume implicaria a existência de uma redação da referida norma. Assim, tanto pode remeter para os tradicionais foros e costumes ${ }^{96}$ quanto para uma prática ou rotina. Por outro lado, se costume e foral são apresentados nos textos como fontes diferenciáveis que, cumulativamente, se enunciam na defesa do direito local ${ }^{97}$, o mesmo não é extensivo às designações de foral ou de foro, dado que são usadas de modo indiscriminado ${ }^{98}$. Por fim, saliente-se

${ }^{93}$ Não se pode excluir totalmente a hipótese de este grupo incluir mandados régios mais genéricos e não especificamente direcionados para um concelho particular, ainda que não tenha sido possível averiguá-lo.

94 Artigo 49 de Lisboa apresentado nas cortes de 1331 (Cortes de D. Afonso IV, pp. 76-77); artigo 20 de Lamego apresentado nas cortes de 1352 (Cortes de D. Afonso IV, p. 146) e artigos 1 e 3 apresentados pelo Porto nas cortes de 1361, referindo-se a mandados régios gerais (Cortes de D. Pedro I, pp. 112-113).

95 Veja-se CAETANO, Marcelo: História do Direito Português. Fontes, Direito Público, 1140-1495, Lisboa, Verbo, $2^{\mathrm{a}}$ edição, 1985, pp. 231-235; CINTRA, Luís Filipe Lindley: A linguagem dos foros de Castelo Rodrigo. Seu confronto com a dos foros de Alfaiates, Castelo Bom, Castelo Melhor, Coria, Cáceres e Usagre. Contribuição para o estudo do leonês e do galego-português do século XIII, Lisboa, Imprensa Nacional-Casa da Moeda, 2a edição, 1984; MATTOSO, José: Identificação de um país. Ensaio sobre as origens de Portugal.1096-1325, vol. I Oposição, Lisboa, Editorial Estampa, 1985, pp. 350-352 e 367-376. Cf. sobre a necessidade de proceder a um esclarecimento jurídico das fontes de direito incluídas nos foros e costumes COELHO, Maria Helena da Cruz: $O$ deve e o haver ..., p. 24.

96 Vejam-se os estudos sobre foros e costumes: COELHO, Maria Helena da Cruz: "Memórias municipais da Guarda", in COELHO, Maria Helena da Cruz e MORUJÃO, Maria do Rosário Barbosa: Forais e Foros da Guarda, Guarda, Câmara Municipal, 1999, pp. 11-34; Id.: "Seia - uma terra de fronteira nos séculos XII-XIII", Homens, Espaços e Poderes (séculos XI-XVI). I. Notas do viver social, 1990, pp. 126-131; id.: Forais de Montemor-o-Velho, Montemor-o-Velho, Câmara Municipal, 2002; id.: "Estudo" in Foral de D. Manuel I a Santarém, pp. 11 e ss.; id.: "O concelho de Torres Novas ...”, in 1190/1990. Foral de Torres Novas, Torres Novas, Câmara Municipal de Torres Novas, pp. 65-67; VILAR, Hermínia Vasconcelos: “A construção da identidade urbana no século XIII. O caso do sul de Portugal”, Anales de la Universidad de Alicante. História Medieval, no 16, (2009-2010), p. 149- (disponível em http://rua.ua.es/dspace/bitstream/10045/17185/1/Historia_Medieval_16_07.pdf, consultado a 2 de Julho de 2012).

${ }^{97}$ Foro, uso e costume: capítulo 1 de Santarém apresentado nas cortes de 1325 (Cortes de D. Afonso IV, p. 13); foral e costume: capítulos 37, 38, 41, 44, 56 e 60 de Lisboa apresentados nas cortes de 1331 (ibid., pp. $72,73,74,75,78,79-25$ ) e capítulo 11 de Coimbra apresentado nas mesmas cortes (ibid., pp. 59/60); foro e costume: capítulos 14 e 15 de Santarém apresentados nas cortes de 1331 (ibid., p. 94); e capítulo 3 de Silves apresentados nas cortes de 1361 (ibid., p. 118).

98 Veja-se, por exemplo, os capítulos 1 e 18 de Sintra apresentados nas cortes de 1331 (Cortes de D. Pedro I, p. 87). 
o recurso à justificação compósita por parte dos concelhos, que acumulam, no mesmo pedido, o foral, o costume e cartas régias ${ }^{99}$.

Na passagem da petição do concelho para a resposta da coroa parece existir, por vezes, uma mudança na especificação do sustentáculo argumentativo. Assim, por exemplo, os povos alegam o foro da terra e o monarca condescende mas em nome do costume ${ }^{100}$; de forma similar, um protesto baseado na letra do foral pode receber a anuência alicerçada no foro e costume antigo ${ }^{101} \mathrm{ou}$, ainda, por a situação descrita ser considerada "sem razão"102. Mais do que qualquer tentativa régia de manipular as fundamentações, deve tratar-se de mera imprecisão da linguagem a causar estas incongruências. Ainda que, sobretudo o último caso enunciado, nos introduza na questão da eficácia do direito enquanto argumento para obter o consentimento régio.

Não tendo sido realizado um cotejo exaustivo ${ }^{103}$, uma simples sondagem permite adiantar que os requerimentos apoiados em forais tinham uma efetiva correspondência no seu articulado ${ }^{104}$; conta-se, inclusivamente, a transcrição de uma cláusula foralenga num capítulo ${ }^{105}$. Ou seja, esta retórica tinha alicerces materiais. Facto que nada tem de estranho, uma vez que as cortes eram aproveitadas pelos procuradores dos concelhos para obterem a confirmação de documentos que já possuíam ${ }^{106}$, como está expressamente mencionado nas cartas régias de onde se recuperam os artigos

${ }^{99}$ Capítulos $\mathrm{n}^{\circ}$ 40, 43, 46 e 54 apresentados às cortes de Lisboa de 1331 (Cortes de D. Afonso IV, pp. $73-$ 75, 78); Capítulo $\mathrm{n}^{\circ} 4$ de Sintra apresentado às mesmas cortes (ibid., pp. 96-97) e capítulo 21 apresentado por Coimbra às cortes de 1361 (Cortes de D. Pedro I, pp. 86-87;

100 Artigos 1, 6, 11 e 23 de Coimbra apresentados à cortes de 1331 (Cortes de D. Afonso IV, pp. 57, 58, 59-60, 62); artigos 8 e 18 apresentados por Sintra às mesmas cortes (ibid., pp. 97, 99); artigo 22 apresentado por Coimbra às cortes de 1361 (ibid., pp. 97, 99).

101 Caso dos capítulos 1, 6, 18 e 23 apresentados por Coimbra nas cortes de 1331 (Cortes de D. Afonso $I V$, pp. 57-58, 61 e 63).

102 Capítulo 14 apresentado por Coimbra nas cortes de 1331 (Cortes de D. Afonso IV, p. 60).

103 Compare-se a letra do foral de Sintra com os argumentos apresentados pelo concelho em 1331 (Cortes de D. Afonso IV, pp. 96 - 100 e COSTA, Francisco: O foral de Sintra (1154): sua originalidade e expressão comunitária, Sintra, Câmara Municipal de Sintra, 1976).

104 Consultem-se os forais respetivos: Lisboa - CAETANO, Marcelo: A Administração municipal de Lisboa durante a $1^{a}$ dinastia (1179-1383), Lisboa, Academia Portuguesa de História, pp. 114-123; Torres Novas - 1190/1990. Foral de Torres Novas, Torres Novas, Câmara Municipal de Torres Novas, 1990; Coimbra - COELHO, Maria Helena da Cruz: "A propósito do foral de Coimbra de 1179", in Homens, Espaços e Poderes. Séculos XI-XVI, vol. I, Notas do Viver Social, Lisboa, 1990, pp. 105-120; Évora - Documentos Medievais Portugueses, introdução e notas de Rui de Azevedo, Lisboa, Academia Portuguesa de História, 1958, Tomo I, pp. 371-373; Bragança - No $8^{\circ}$ Centenário do $1^{\circ}$ Foral de Bragança, textos e coordenação de José Rodrigues Monteiro, Bragança, Câmara Municipal de Bragança/Instituto Politécnico de Bragança, 1988; SILVES - Forais de Silves, Estudo histórico de Manuela Santos Silva; Tradução de Maria Filomena Andrade, Silves, Câmara Municipal de Silves, 1993; Sintra - COSTA, Francisco, O foral de Sintra (1154): sua originalidade e expressão comunitária ...; Montemor-o-Velho - COELHO, Maria Helena da Cruz: Forais de Montemor-o-Velho .... ; Santarém - SOARES, Lina Maria Marques: Foral Antigo de Santarém. Edição Crítica e Estudo, Lisboa, Edições Colibri, 2005.

105 Capítulo 46 de Lisboa, apresentado nas cortes de 1331 (Cortes de D. Afonso IV, p. 75).

106 Veja-se o que escreve Ana Filipa Roldão quanto à categoria documental “Cortes”, inserta no inventário do arquivo da câmara de Évora, elaborado cerca de 1415. Segundo a autora, este conjunto de documentos destaca-se no inventário, tanto pela sua quantidade quanto por ser descrito o seu conteúdo (A memória urbana da cidade. A administração urbana e práticas de escrita em Évora (1415-1536) ... pp. 32-33. 
especiais $^{107}$. Em consonância, do lado régio, apelava-se à visualização das provas insertas em livros antigos ${ }^{108}$.

\section{TIPOLOGIA DA ARGUMENTAÇÃO DOS CAPÍTULOS ESPECIAIS}

\begin{tabular}{|c|c|c|c|c|}
\hline $\begin{array}{l}\text { CORTES } \\
\text { ARGUMENTO } \\
\end{array}$ & $\underline{1325}$ & $\underline{1331}$ & $\underline{1352}$ & $\underline{1361}$ \\
\hline $\begin{array}{l}\text { Ausência de sustentáculo } \\
\text { argumentativo }\end{array}$ & Santarém (6) & $\begin{array}{l}\text { Bragança (1) } \\
\text { Coimbra (5) } \\
\text { Lisboa (19) } \\
\text { Porto (11) } \\
\text { Santarém (3) } \\
\text { Sintra (6) }\end{array}$ & Lamego (12) & $\begin{array}{l}\text { Coimbra (6) } \\
\text { Évora (5) } \\
\text { Lisboa (2) } \\
\text { Montemor-o-Velho (2) } \\
\text { Porto (10) } \\
\text { Silves (1) } \\
\text { Torres Novas (6) } \\
\end{array}$ \\
\hline $\begin{array}{l}\text { Defesa de valores morais e } \\
\text { políticos }\end{array}$ & & $\begin{array}{l}\text { Coimbra (4) } \\
\text { Lisboa (12) } \\
\text { Santarém (2) } \\
\end{array}$ & Lamego (1) & $\begin{array}{l}\text { Coimbra (2) } \\
\text { Évora (1) } \\
\text { Porto (1) } \\
\end{array}$ \\
\hline $\begin{array}{l}\text { Defesa da ordem das coisas } \\
\text { Contra inovação de práti- } \\
\text { cas, procedimentos, leis e } \\
\text { mandados régios }\end{array}$ & Santarém (1) & $\begin{array}{l}\text { Coimbra (6) } \\
\text { Lisboa (15) } \\
\text { Porto (3) } \\
\text { Santarém (1) } \\
\text { Sintra (1) }\end{array}$ & Lamego (8) & $\begin{array}{l}\text { Coimbra (13) } \\
\text { Évora (4) } \\
\text { Lisboa (1) } \\
\text { Montemor-o-Velho (3) } \\
\text { Porto (3) } \\
\text { Silves (2) } \\
\text { Torres Novas (1) } \\
\end{array}$ \\
\hline $\begin{array}{l}\text { Analogia com outros con- } \\
\text { celhos }\end{array}$ & & & Lamego (1) & Torres Novas (2) \\
\hline \multicolumn{5}{|l|}{ Defesa da ordem jurídica } \\
\hline Foral, Foro e costume & Santarém (2) & $\begin{array}{l}\text { Coimbra (6) } \\
\text { Lisboa (32) } \\
\text { Porto (1) } \\
\text { Santarém (9) } \\
\text { Sintra (12) } \\
\end{array}$ & Lamego (1) & $\begin{array}{l}\text { Coimbra (8) } \\
\text { Évora (1) } \\
\text { Montemor-o-Velho (1) } \\
\text { Silves (4) }\end{array}$ \\
\hline $\begin{array}{l}\text { Cartas, mercês ou mandados } \\
\text { régios }\end{array}$ & Santarém (3) & \begin{tabular}{|l|} 
Coimbra (3) \\
Lisboa (4) \\
Santarém (3) \\
Sintra $(2)^{109}$ \\
\end{tabular} & Lamego (2) & Coimbra (2) \\
\hline Composição & & Porto (2) & & \\
\hline Lei régia & & Lisboa (1) & Lamego (1) & Porto (2) \\
\hline $\begin{array}{l}\text { Inadequação da ordem } \\
\text { jurídica local (Foros e } \\
\text { costumes) }\end{array}$ & & Bragança (4) & & \\
\hline
\end{tabular}

107 Veja-se o preâmbulo dos capítulos de Santarém apresentados às cortes de 1325 - Cortes de D. Afonso IV , p. 13), dos capítulos de Bragança apresentados às cortes de 1331 (ibid., p. 54) e dos capítulos de Santarém levados às mesmas cortes (ibid., p. 90).

${ }^{108}$ Veja-se a resposta ao capítulo ${ }^{\circ} 1$ apresentado por Coimbra nas cortes de 1361 (Cortes de D. Pedro I, p. 79-80).

${ }^{109}$ Uma das ordens foi dada pelo infante e não pelo rei. Veja-se o capítulo 11 de Sintra apresentado nas cortes de 1331 (Cortes de D. Afonso IV, pp. 97-98). 
Dir-se-ia que este levantamento da argumentação dos capítulos especiais de cortes, no que à ordem jurídica diz respeito, ilustra as palavras de António Manuel Hespanha sobre a eficácia do privilégio face à lei real, ainda na Época Moderna ${ }^{110}$. Aliás, a organização dos capítulos gerais apresentados na assembleia reunida em Santarém no ano de 1331 é eloquente quanto à primazia dos foros e costumes locais. Como contraditório do panorama antes enunciado, encontra-se um rol de quatro requerimentos para reformular parte da normativa de expressão local, em Bragança. Mas trata-se de um caso isolado ${ }^{111}$.

Se os motivos jurídicos dos pedidos se relacionam preferencialmente com o particularismo, o mesmo não acontece sempre com as respostas da coroa. Apreende-se um movimento no sentido da sistematização legislativa, pelo qual o monarca apela a uma norma geral que englobe o que se encontra consignado nos inúmeros privilégios recebidos pontualmente pelos concelhos, ao longo dos tempos ${ }^{112}$.

Em meados do século XIV, uma leitura transversal dos capítulos especiais de cortes permite concluir pela existência de uma nítida valorização da ordem jurídica local. Caso para épocas posteriores se verificar uma importância acrescida de outros sustentáculos argumentativos, a análise no tempo das justificações que usam os povos corresponderá a um excelente barómetro de apreensão de transformações ocorridas na cultura política e, em especial, num dos elementos que a integra, a ordem jurídica.

Atualizemos os propósitos deste artigo. Pretendia-se estudar situações em que fosse apreensível o ambiente mental que preside ao diálogo estabelecido entre a coroa e os concelhos em meados do século XIV. Não se tratava de identificar o que os concelhos almejavam obter com a apresentação dos seus protestos, mas as alegações em que se baseavam para justificar a bondade ou a justeza das suas pretensões e, do lado da coroa, a anuência ou rejeição às mesmas.

E porque foi eleito como nuclear neste estudo, o alheio (e adulterado) conceito de cultura política? Porque se trata de uma categoria operacional, desde que aplicada não a um conjunto alargado de pessoas de comunguem de uma determinada cultura com repercussões no agir político mas acantonada ao grupo dos líderes das várias subestruturas do sistema político medieval português. Esta noção fornece-nos a base para apreender os mecanismos que permitiam ao sistema funcionar. Com efeito, a definição de ordem jurídica não abarca todas as componentes que agem neste diálogo, nomeadamente a autoimagem que as comunidades constroem para consumo externo ou os fundamentos da ideologia régia.

110 Veja-se do autor: "O foral novo de Évora no contexto da reforma dos forais de D. Manuel I", in Foral Manuelino de Évora, Câmara Municipal - Imprensa Nacional Casa da Moeda, (2001), pp. 51 e ss.

111 Como é o caso do concelho de Bragança que, em 1331, solicita ao rei que os seus foros e costumes sejam alterados, não sem antes apresentar o trelado do foro e dos costumes e das cartas das graças dos reis (Cortes de D. Afonso IV, p. 55).

112 Veja-se, por exemplo, o caso do capítulo $2^{\circ}$ apresentado por Santarém nas cortes de 1325 , sustentado numa carta régia anterior passada ao concelho que não se encontrava a ser respeitada; pela letra desse mandado, o alcaide não devia prender vizinhos e levá-los à prisão antes de serem presentes a juízes. Afonso IV limita-se a confirmar tal diploma (Cortes de D. Afonso IV,pp. 13-14). Em 1331, Coimbra apresenta um artigo, o $2^{\circ}$, que é em tudo similar ao anterior, alegando também que o concelho tinha cartas de D. Afonso III, confirmadas por D. Dinis e pelo próprio Afonso IV. Desta feita, o monarca reenvia o concelho para as respostas dadas nos capítulos gerais (ibid., p. 57). 
Recordemos a premissa que nos serviu de mote: as crenças sobre os fundamentos do poder e as normas do seu exercício captam-se com base na argumentação dos pedidos e das respostas régias. A validade desta premissa necessita de estudos aprofundados, nomeadamente a comparação com o que irá acontecer em reinados subsequentes de forma a avaliar até que ponto se verificou a receção da cultura jurídica acalentada pela coroa ou se as justificações aduzidas pelos povos se mantêm inalteráveis. 